\title{
Efek Kapsul Ekstrak Etanol Kelopak Bunga Rosella (Hibiscus sabdariffa L.) terhadap Kadar Bilirubin
} Sukarelawan Sehat

Nur Azizah $^{1,2 *}$, Endang Darmawan ${ }^{1}$, Laela Hayu Nurani ${ }^{1}$

${ }^{1}$ Fakultas Farmasi, Universitas Ahmad Dahlan, Yogyakarta

${ }^{2}$ Akademi Farmasi Muhammadiyah, Kuningan, Jawa Barat

*Corresponding author: mom_zie80@yahoo.co.id

\begin{abstract}
Background: Hibiscus sabdariffa is one of traditional herbs that has a lot of benefits including immunostimulant effect, because it contains antioxidant compunds including anthocyanin and flavonoid. Based on its activity on preclinical tests, H.sabdariffa has been qualified to proceed to clinical trial phase. Objective: The study aimed to investigate the effect of ethanol extract capsule of rosella petals (Hibiscus sabdariffa L.) on bilirubin levels on 11 healthy male volunteers and 10 healthy female volunteers. Methods: This study used pre-and post treatment design. Healthy volunteers consume ethanol extract capsule of rosella petals for 30 days at a dose of $500 \mathrm{mg}$ once daily at night. Bilirubin test was conducted at day 0; 31 and 45, using Jendrassik and Grof method. Results were analyzed using SPSS with paired t-test and Wilcoxon test. Results: The result showed that the comparison of the mean value at day 0 and 31, with day 31 and 45, and the comparison of the mean value between day 0 and 45 showed no significant difference regarding total and direct $(p>0.05)$ and indirect bilirubin levels $(p=0.05)$, but this is still within the normal range of values for indirect bilirubin. Conclusion: The ethanol extract capsule of rosella petals had no affects on total, direct and indirect bilirubin levels in healthy volunteers.
\end{abstract}

Keywords: ethanol, Hibiscus sabdariffa, bilirubin levels

\begin{abstract}
Abstrak
Pendahuluan: Hibiscus sabdariffa adalah salah satu ramuan tradisional yang memiliki banyak manfaat termasuk efek imunostimulan, karena banyak mengandung antioksidan di dalamnya termasuk anthocyanin dan flavonoid. Berdasarkan aktivitasnya pada tes praklinis, H.sabdariffa telah memenuhi syarat untuk melanjutkan ke fase uji klinis. Tujuan: Penelitian ini bertujuan untuk mengetahui pengaruh kapsul ekstrak etanol kelopak bunga rosella (Hibiscus sabdariffa L.) pada kadar bilirubin 11 sukarelawan sehat pria dan 10 sukarelawan sehat wanita. Metode: Penelitian ini menggunakan rancangan pre-post treatment. Sukarelawan sehat mengkonsumsi kapsul ekstrak etanol kelopak bunga rosella selama 30 hari dengan dosis $500 \mathrm{mg}$ sekali sehari pada malam hari. Tes Bilirubin dilakukan pada hari ke-0; 31 dan 45, menggunakan metode Jendrassik dan Grof. Hasil dianalisis menggunakan SPSS dengan paired t-test dan uji Wilcoxon. Hasil: Perbandingan nilai rata-rata pada hari ke-0 dan 31, dengan hari ke-31 dan 45, dan perbandingan nilai rata-rata antara hari ke-0 dan ke-45 tidak menunjukkan perbedaan yang signifikan pada kadar bilirubin total dan direct $(\mathrm{p}>0,05)$, sedangkan perbandingan nilai rata-rata untuk kadar bilirubin indirect hari ke-0 dan ke-45 menunjukkan adanya perbedaan yang signifikan $(\mathrm{p}=0,05)$ akan tetapi kadar bilirubin indirect tersebut masih dalam rentang nilai normal. Kesimpulan: Kapsul ekstrak etanol kelopak bunga rosella tidak mempengaruhi kadar bilirubin total, direct dan indirect pada sukarelawan sehat.
\end{abstract}

Kata kunci: etanol, Hibiscus sabdariffa, kadar bilirubin

\section{PENDAHULUAN}

Hibiscus sabdariffa (rosella) adalah salah satu tanaman tradisional yang memiliki banyak manfaat bagi kesehatan tubuh. Kandungan senyawa yang terdapat dalam rosella terdiri dari antosianin, polisakarida, hydroxycitric acid, hibiscus acid dan flavonoid yang dapat berperan sebagai antioksidan.
Selain itu juga rosella memiliki kandungan vitamin B1, B2, niasin, vitmin D serta 18 asam amino (Da- CostaRocha dkk., 2014; Mardiah dkk., 2009; Rahmawati, 2012). Sifat antioksidan yang dimiliki rosella dapat meningkatkan sistem imun dengan cara melindungi sel-sel tubuh dari radikal bebas dan kerusakan akibat paparan sinar ultraviolet (Mardiah dkk., 2009). 
Sifat antioksidan yang dimiliki oleh rosella disebabkan karena kandungan antosianinnya. Penelitian yang dilakukan oleh Wijaya dkk. (2014) membuktikan bahwa antosianin yang terkandung dalam rosella dengan dosis $100 \mathrm{mg} / \mathrm{KgBB}$ mampu menurunkan kadar malondialdehide pada tikus yang hiperkolesterol, sedangkan penelitian yang dilakukan oleh Nurkhasanah \& Rahardhian (2015), menyatakan bahwa aktivitas antioksidan rosella mampu melindungi hati hewan uji dari kerusakan akibat radikal bebas (DMBA). Efek antioksidan rosella juga mampu melindungi hati dari kerusakan akibat paparan radikal bebas dengan menurunkan kadar enzim-enzim pada hati. Penelitian yang dilakukan oleh Bhavana dkk. (2017) menyatakan bahwa ekstrak air daun rosella merah yang diberikan secara oral tidak menunjukkan adanya kerusakan pada hati tikus yang diinduksi oleh alkohol dengan menurunkan kadar bilirubin. Olanrewaju dkk., (2017) menyatakan bahwa ekstrak metanol kelopak bunga rosella memiliki efek hepatoprotektif dengan menurunkan kadar bilirubin pada tikus yang diinduksi berulangkali dengan etanol.

Berdasarkan penelitian yang dilakukan oleh Nurkhasanah (2015) terhadap hewan uji menyatakan bahwa pada dosis $50 \mathrm{mg} / \mathrm{KgBB}$ ekstrak kelopak bunga rosella memberikan potensi terapi sebagai imunostimulator, akan tetapi tidak memberikan potensi toksik (dosis dapat ditoleransi), maka diharapkan ini dapat digunakan pada manusia. Salah satu parameter yang digunakan dalam mentolerir dosis adalah mengetahui adanya perubahan pada fungsi hati (kadar enzim-enzim hati) yang merupakan salah satu rangkaian dalam uji klinik fase 1 (Robinson dkk., 2009). Efek obat terhadap fungsi hati sangat berkaitan dengan efek toksik dalam penelitian keamanan suatu obat. Pengujian keamanan terhadap obat baru yang berasal dari bahan alam amatlah perlu untuk mengetahui apakah dosis obat tersebut aman untuk digunakan dan tidak menimbulkan efek toksik.

Ekstrak etanol kelopak bunga rosella memiliki nilai toksisitas $\mathrm{LD}_{50}$ sebesar $850,90 \mathrm{mg} / \mathrm{KgBB}$ pada tikus sprague dawley dengan kategori toksisitas ringan dan tidak memiliki pengaruh terhadap aktivitas enzim SGOT, SGPT, ALP, dan bilirubin (Sari dkk., 2016; Bhavana dkk., 2017) yang mana enzim-enzim tersebut merupakan indikator adanya kerusakan atau kelainan pada hati. Suwandi (2012) juga melaporkan bahwa ekstrak etanol kelopak bunga rosella pada tikus memiliki $\mathrm{LD}_{50}$ sebesar $\geq 15 \mathrm{~g} / \mathrm{KgBB}$ hasil tersebut masuk ke dalam kategori praktis tidak toksis. Pemanfaatan rosella seperti saat ini perlu diimbangi dengan informasi kepastian keamananya terhadap manusia. Beberapa penelitian yang telah dilakukan terhadap hewan uji menimbulkan pertanyaan mengenai kemanan dari $H$. sabdariffa (rosella) terhadap manusia. Penelitian ini dilakukan untuk dapat mengetahui bagaimana pengaruh setelah mengkonsumsi ekstrak etanol kelopak bunga rosella yang dikemas dalam kapsul terhadap kadar bilirubin sukarelawan sehat.

\section{BAHAN DAN METODE \\ Bahan}

Bahan yang digunakan pada penelitian ini adalah kapsul yang berisi serbuk ekstrak etanol kelopak bunga rosella terstandari yang di peroleh dari PT. Natura (Product code: 5055C, Batch: RH162703). Reagen yang digunakan untuk mengukur kadar bilirubin adalah reagen bilirubin total dan direct Clona test, REF CT 1009050)

\section{Alat}

Alat yang digunakan adalah Random Acces Clinical Analyzer Metrolab 2300 plus dengan metode Jendrassik dan Grof, tabung mikrosentrifugasi berisi ethylenediaminetetraacetic acid (EDTA) sebagai antikoagulan, spuit $5 \mathrm{cc}$, tensimeter (Corona), falcon, vortex Mixer (FV-2400 Microspin Biosan, $220 \mathrm{~V}$, $60 \mathrm{~Hz})$

\section{Metode}

Penelitian ini merupakan penelitian pre and post treatment. Subjek yang digunakan adalah sukarelawan sehat yang berjumlah 21 orang terdiri 11 orang lakilaki dan 10 orang perempuan (jumlah tersebut sesuai dengan ketentuan BPOM RI (2014), mengenai jumlah subjek dalam penelitian uji klinik fase I yaitu 20 - 80 orang). Sukarelawan sehat yang dapat mengikuti penelitian ini harus memenuhi kriteria inklusi, yaitu sehat dibuktikan dengan surat keterangan dari dokter, usia 18 - 45, IMT $18-30 \mathrm{Kg} / \mathrm{m}^{2}$, tidak merokok, tidak mengkonsumsi herbal lain atau vitamin dan suplemen. Kriteria eksklusi dari penelitian ini yaitu wanita hamil dan menyusui, memiliki faktor resiko penyakit imun seperti lupus dan leukemia, memiliki riwayat gangguan fungsi hati dan fungsi ginjal.

Sukarelawan sehat diberi kapsul yang berisi ekstrak etanol kelopak bunga rosella selama 30 hari dengan dosis $500 \mathrm{mg}$ sebanyak 1 kali sehari, setelah makan pada malam hari. Pemeriksaan kadar bilirubin dilakukan pada hari ke-0 (sebelum mengkonsumsi); ke31 (setelah mengkonsumsi) dan ke-45 (15 hari setelah tidak mengkonsumsi) dengan menggunakan metode metode Jendrassik dan Grof. 


\section{Persiapan dan pemeriksaan kesehatan}

Penelitian diawali dengan pengajuan Ethical Clearance kepada Komite Etik Fakultas Kedokteran dan Ilmu Kesehatan Universitas Muhammadiyah Yogyakarta. Kelayakan etika dari penelitian ini dibuktikan dengan terbitnya surat keterangan layak etik (Ethical Clearance) dengan nomor 255/EP-FKIKUMY/IV/2017.

\section{Pemeriksaan kesehatan}

Relawan yang telah menyetujui informed consent diperiksa oleh dokter bersertifikat untuk menentukan kesesuaian kriteria sehat. Kriteria sehat meliputi vital sign, yaitu tekanan darah (TD), suhu tubuh, denyut nadi (heart rate, HR) dan tingkat pernapasan (respiration rate, RR), hasil pemeriksaan dokter dinyatakan dalam surat keterangan sehat dengan didukung oleh pemeriksaan laboratorium klinis yang meliputi bilirubin total, langsung dan tidak langsung.

\section{Persiapan pengambilan sampel darah}

Sampel darah diambil pada median cubital vein atau brachial vein dengan menggunakan jarum suntik 5 cc untuk darah 4 cc. Sampel kemudian disimpan di tabung mikro sentrifugal yang mengandung EDTA sebagai koagulan. Pemisahan plasma dilakukan dengan sentrifugasi dengan kecepatan $3.500 \mathrm{rpm}$ selama 5 menit, kemudian diambil larutan yang berwarna kuning jernih (serum) (Khasanah, 2016)

\section{Pemeriksaan bilirubin}

Penetapan kadar bilirubin ditetapkan berdasarkan metode Jendrassik \& Grof (1938) menggunakan alat autoanalyzer spectrophotometer dengan prinsip bilirubin akan membentuk senyawa azo berwarna merah dalam larutan alkali dengan adanya garam diazonium asam sulfonat (panjang gelombang 546 $\mathrm{nm})$. Prosedur kerja pemeriksaan bilirubin total adalah campurkan $40 \mu \mathrm{l}$ reagen nitrit total dengan $1000 \mu \mathrm{L}$ reagen bilirubin total kemudian tambahkan $100 \mu \mathrm{L}$ serum, inkubasi campuran selama 10 - 30 menit pada suhu kamar lalu ukur pada panjang gelombang $546 \mathrm{~nm}$. Prosedur kerja untuk pemeriksaan bilirubin direct adalah campurkan $40 \mu \mathrm{l}$ reagen nitrit direct dengan $1000 \mu \mathrm{L}$ reagen bilirubin direct kemudian tambahkan $100 \mu \mathrm{L}$ serum, inkubasi campuran selama $10-30$ menit pada suhu kamar lalu ukur pada panjang gelombang $546 \mathrm{~nm}$.

Total Bilirubin $=$ Bilirubin Direct + Bilirubin Indirect

\section{Analisis data}

Analisis data dihitung secara continue dengan menyajikan mean \pm SD menggunakan statistik SPSS 20. Hasil pemeriksaan bilirubin total, direct dan indirect pada sukarelawan sehat yang diukur pada hari ke-0 (sebelum mengkonsumsi), hari ke-31 (setelah mengkonsumsi) dan hari ke-45 (15 hari setelah tidak mengkonsumsi) diuji terlebih dahulu normalitasnya dengan uji Shapiro-Wilk. Selanjutnya, jika data terdistribusi normal dianjutkan dengan melakukan paired t-test, sedangkan jika tidak terdistribusi normal maka analisis dilanjutkan dengan melakukan uji Wilcoxon pada taraf kepercayaan 95\% (Dahlan, 2014).

\section{HASIL DAN PEMBAHASAN}

Hasil pemeriksaan perbandingan rata-rata bilirubin total dan direct sukarelawan sehat yang diberi kapsul ekstrak etanol kelopak bunga rosella menunjukkan tidak ada perbedaan bermakna karena nilai $\mathrm{p}>0,05$, sedangkan untuk kadar bilirubin indirect ditemukan perdaan dalam rata-rata antara hari ke 0-45 ( $\mathrm{p}=0,05)$. Secara klinis tingkat kadar bilirubin masih dalam batas normal. Hasil penelitian dapat dilihat pada Tabel 1.

Tabel 1. Rata-rata Nilai Bilirubin Sukarelawan Sehat yang diberi Kapsul Ekstrak Etanol Kelopak Bunga Rosella ( $\mathrm{n}=$ 21).

\begin{tabular}{|c|c|c|c|c|c|c|c|}
\hline \multirow{2}{*}{$\begin{array}{l}\text { Parameter } \\
\text { Fungsi Hati }\end{array}$} & \multicolumn{3}{|c|}{$\begin{array}{c}\text { Rata-rata Nilai Fungsi Hati Sukarelawan } \\
\text { Sehat (Mean } \pm \text { SD) }\end{array}$} & \multicolumn{3}{|c|}{$\mathrm{P}$ value } & \multirow{2}{*}{ Nilai Normal } \\
\hline & Hari Ke-0 & Hari Ke-31 & Hari Ke-45 & $\begin{array}{c}\text { Hari Ke } \\
0-31\end{array}$ & $\begin{array}{c}\text { Hari Ke } \\
31-45\end{array}$ & $\begin{array}{c}\text { Hari Ke } \\
0-45\end{array}$ & \\
\hline Total Bilirubin & $0,69 \pm 0,46$ & $0,77 \pm 0,41$ & $0,74 \pm 0,41$ & 0,140 & 0,639 & 0,237 & $\leq 1,4 \mathrm{mg} / \mathrm{dL}$ \\
\hline $\begin{array}{l}\text { Direct } \\
\text { Bilirubin }\end{array}$ & $0,39 \pm 0,10$ & $0,46 \pm 0,21$ & $0,42 \pm 0,11$ & 0,125 & 0,363 & 0,324 & $\leq 0,4 \mathrm{mg} / \mathrm{dL}$ \\
\hline $\begin{array}{l}\text { Indirect } \\
\text { Bilirubin }\end{array}$ & $0,22 \pm 0,34$ & $0,13 \pm 0,19$ & $0,12 \pm 0,21$ & 0,186 & 0,806 & 0,050 & $\leq 1,0 \mathrm{mg} / \mathrm{dL}$ \\
\hline
\end{tabular}

Keterangan: Nilai Normal Kadar Bilirubin (Kemenkes RI, 2011)

Pengukuran kadar bilirubin menggunakan alat Random Acces Clinical Analyzer Metrolab 2300 plus dengan metode Jendrassik \& Grof (1938). Pengukuran kadar bilirubin dilakukan sebelum sukarelawan sehat 
mengkonsumsi kapsul ekstrak etanol kelopak bunga rosella (hari ke-0), setelah mengkonsumsi kapsul ekstrak etanol kelopak bunga rosella (hari ke-31) dan setalah 15 hari tidak mengkonsumsi kapsul ekstrak etanol kelopak bunga rosella (hari ke-45). Data hasil analisis kadar bilirubin yang disajikan pada Tabel 1 menunjukkan adanya perubahan rata-rata nilai bilirubin total, direct dan indirect sukarelawan sehat. Kadar bilirubin total hari ke-0 adalah 0,69 mg/dL, untuk hari ke-31 adalah 0,77 $\mathrm{mg} / \mathrm{dL}$ dan hari ke-45 adalah 0,74 $\mathrm{mg} / \mathrm{dL}$. Kadar bilirubin direct di hari ke-0 adalah 0,39 $\mathrm{mg} / \mathrm{dL}$, hari ke-31 adalah $0,46 \mathrm{mg} / \mathrm{dL}$ dan hari ke- 45 adalah $0,42 \mathrm{mg} / \mathrm{dL}$ sedangkan untuk hasil pengukuran kadar bilirubin indirect hari ke- 0 adalah $0,22 \mathrm{mg} / \mathrm{dL}$, hari ke-31 adalah $0,13 \mathrm{mg} / \mathrm{dL}$ dan hari ke-45 adalah $0,12 \mathrm{mg} / \mathrm{dL}$. Hasil analisis perbandingan rata-rata kadar bilirubin total dan direct hari ke-0 dan hari ke-31 dengan hari ke-31 dan hari ke-45 dan perbandingan antara hari ke-0 dan ke-45 tidak terdapat perbedaan yang bermakna karena nilai $\mathrm{p}>0,05$, sedangkan untuk kadar bilirubin indirect pada perbandingan hari ke-0 dan ke-45, terdapat perbandingan bermakna karena $\mathrm{p}=$ 0,05 , namun nilai kadar masih dalam rentang nilai normal. Perubahan yang terjadi pada setiap kali pengukuran masih dalam rentang nilai normal sehingga hasil ini dapat disimpulkan bahwa kapsul ekstrak etanol kelopak bunga rosella secara klinis relatif aman karena tidak mempengaruhi jumlah kadar bilirubin total, direct dan indirect pada sukarelawan sehat. Nilai kadar bilirubin normal menurut Kemenkes RI (2011) adalah bilirubin total sebesar $\leq 1,4 \mathrm{mg} / \mathrm{dL}$, bilirubin direct sebesar $\leq 0,4 \mathrm{mg} / \mathrm{dL}$ dan untuk kadar bilirubin indirect sebesar $\leq 1,0 \mathrm{mg} / \mathrm{dL}$.

Hasil penurunan nilai bilirubin yang didapat ini sejalan dengan penelitian sebelumnya bahwa, ekstrak kelopak bunga rosella memiliki efek hepatoprotektif dengan menurunkan aktivitas bilirubin (Bhavana dkk., 2017 dan Olanrewaju dkk., 2017).

Peningkatan kadar bilirubin direct dapat disebabkan obstruksi biliar intrahepatik dan ekstrahepatik, juga disebabkan oleh kerusakan sel-sel parenkim hepar. Bilirubin indirect adalah bilirubin yang belum mengalami konjugasi di hepar. Bilirubin direct merupakan bilirubin indirect yang telah mengalami tiga tahap metabolisme (pengambilan, konjugasi, dan ekskresi), bersifat larut dalam air dan dapat diekskresikan ke dalam urin (Panjaitan dkk., 2011).

Perubahan kadar bilirubin total dan direct pada sukarelawan sehat menunjukkan bahwa perubahan tersebut memiliki perbedaan nilai yang tidak bermakna atau perubahan tersebut tidak signifikan karena nilai p > 0,05 sedangkan untuk kadar bilirubin indirect pada sukarelawan di hari ke-0-45 menunjukkan adanya perubahan yang signifkan $\mathrm{p}=0,05$ namun kadar bilirubin masih dalam rentang nilai normal. Meskipun secara statistik mengalami perubahan dari tiap-tiap parameter namun secara klinis tidak bermakna. Penurunan kadar bilirubin pada sukarelawan sehat disebabkan karena kandungan antioksidan dan flavonoid dalam ekstrak etanol kelopak bunga rosella sehingga dapat melindungi fungsi hati, ini sejalan dengan penelitian Mardiah dkk. (2009) yang menyatakan bahwa pigmen antosianin yang terkandung dalam rosella berfungsi sebagai antioksidan, yang mampu menjaga fungsi hati dari krusakan akibat radikal bebas. Selain itu Bhavana dkk. (2017) menyatakan aktivitas hepatoprotektif Hibiscus sabdariffa dapat disebabkan oleh adanya bioflavonoid yang memiliki sifat hepatoprotektif.

\section{KESIMPULAN}

Hasil penelitian menunjukkan bahwa kapsul ekstrak etanol kelopak bunga rosella selama 30 hari tidak memberikan efek terhadap nilai bilirubin total, direct dan indirect sukarelawan sehat.

\section{UCAPAN TERIMA KASIH}

Hibah penelitian unggulan Program Studi dari LPP Universitas Ahmad Dahlan Yogyakarta tahun 2017.

\section{DAFTAR PUSTAKA}

Badan Pengawas Obat dan Makanan Republik Indonesia (BPOM RI). (2014). Peraturan Kepala Badan Pengawas Obat dan Makanan Republik Indonesia Nomor 13 tentang Pedoman Uji Klinik Obat Herbal. Jakarta: BPOM RI.

Bhavana, G. R., Rajani, Mai, Babu, J. \& Bonthagarala, B. (2017). Hepatoprotective Activity of Aqueous Extract of Hibiscus sabdariffa on Alcohol Induced Hepatotoxity in Rats. World Journal of Pharmacy and Pharmaceutical Science; 6; 767778.

Da-Costa-Rocha, I., Bonnlaender, B., Pischela, I. \& Heinrich, M. (2014). Hibiscus sabdariffa L. A Phytochemical and Pharmacological review. Journal Food Chemistry; 424-443.

Dahlan, S. (2014). Statistik Untuk Kedokteran dan Kesehatan Edisi. 6. Jakarta: Epidemiologi Indonesia.

Jendrassik, L. \& Grof, P. (1938). Estimation of Total Serum Bilirubin Level by Spectrophotometrically 
in Serum and Plasma. Biochem Zeitschrift; 297; 81-89.

Kementrian Kesehatan Republik Indonesia (Kemenkes RI). (2011). Pedoman Interpretasi Data Klinik. Jakarta: Kemenkes RI.

Khasanah, U. (2016). Perbedaan Hasil Pemeriksaan Hitung Jumlah Trombosit pada Darah Vena dan Darah Kapiler dengan Metode Tabung. Skripsi; Fakultas Ilmu Keperawatan dan Ilmu Kesehatan Universitas Muhammadiyah, Semarang.

Mardiah, Hasibuan, S., Ashadi, R. W. \& Rahayu, A. (2009). Budi Daya dan Pengolahan Rosela Si Merah Segudang Manfaat. Jakarta: Agromedia Pustaka.

Nurkhasanah. (2015). The Effect of Rosella (Hibiscus sabdariffa L.) Treatment on IL-10 and IL-14 Secretion on Dimethylbenz $(\alpha)$ Antrachene (DMBA). International Journal Pharmaceutical Science; 7; 402-402.

Nurkhasanah \& Rahardhian, M. R. R. (2015). Hepatoprotective Effect of Hibiscus sabdariffa $\mathrm{L}$ Extract on 7,12-dimethylbenz( $\alpha$ )antracene (DMBA) Induced Rat. International Journal of Biological and Medical Research; 6; 4705-4708.

Olanrewaju, E., Anyaehie, B., Ezeh, C. O., Onyekwelu, K. C. \& Ezeh, R. C. (2017). Effect of Methanolic Extract of Hibiscus sabdariffa in EthanolInduced Hepatotoxicity. African Journal Biomedical Research; 20; 99-102.

Panjaitan, R. G. P., Handharyani, E., Chairul \& Manalu, W. (2013). Hepatoprotective Activity of
Eurycoma longifolia Jack. Roots. Indian Journal of Traditional Knowledge; 12; 225-230.

Rahmawati, R. (2012). Budidaya Rosella. Yogyakarta: Penerbit Pustaka Baru Press.

Robinson, S., Kathryn, C., Shirley, H., Sue S., Derrick Spencer-Briggs, Andy D., Rose H., David E., Brigitte M., Fulcrum P., Sally O., Christopher B. (2009). Guidance on Dose Level Selection of Regulatory General Toxicology Studies for Pharmaceuticals. UK: The Association of the British Pharmaceutical Industry (ABPI) and the British Toxicology Society (BTS).

Sari, F., Nurkhasanah \& Moch, S. B. (2016). Uji Toksisitas Akut Ekstrak Etanol Kelopak Rosella (Hibiscus sabdariffa L.) dan Pengaruhnya terhadap Fungsi Hepar. Tesis; Program Pascasarjana Farmasi Universitas Ahmad Dahlan, Yogyakarta.

Suwandi, T. (2012). Pengembangan Potensi Antibakteri Kelopak Bunga Hibiscus sabdariffa L. terhadap Streptococcis Sanguinis Penginduksi Ginvitis Menuju Obat Herbal Terstandar. Disertasi; Fakultas Kedokteran Gigi Universitas Indonesia, Jakarta.

Wijaya, A., Nurani, L. H. \& Nurkhasanah. (2014). Aktivitas Antioksidan Sediaan Nanopertikel Kitosan Ekstrak Etanol Kelopak Rosella (Hibiscus sabdariffa L.) pada Tikus Hiperkolesterol: Pengukuran Kadar Melondialdehid (MDA). Kartika Jurnal Ilmiah Farmasi; 2; 1-6. 